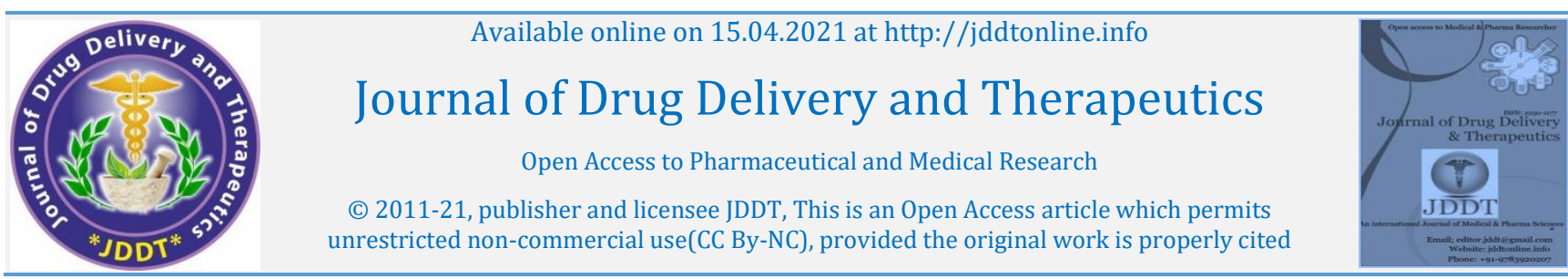

(C) 2011-21, publisher and licensee JDDT, This is an Open Access article which permits

Open Access Full Text Article

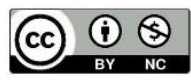

Research Paper

\title{
Preliminary Phytochemical Appraisal of Selected Medicinal Plants
}

\author{
Mohan E1 ${ }^{1}$, Suriya $\mathrm{S}^{2}$, Shanmugam S1*, Muthupandi $\mathrm{CP}^{1}$, Rajendran $\mathrm{K}^{1}$ \\ ${ }^{1}$ Post Graduate and Research Department of Botany, Thiagarajar College, Teppakulam, Madurai - 625009, Tamil Nadu, India
}

${ }^{2}$ Department of Botany, Yadava College, Tiruppalai, Madurai - 625014, Tamil Nadu, India

\begin{tabular}{ll}
\hline Article Info: & \\
\hline ⿴囗口 & Article History: \\
& Received 17 Feb 2021 \\
& Accepted 02 April 2021 \\
& Available online 15 April 2021
\end{tabular}

Cite this article as:

Mohan E, Suriya S Shanmugam S, Muthupandi CP, Rajendran K, Preliminary Phytochemical Appraisal of Selected Medicinal Plants, Journal of Drug Delivery and Therapeutics. 2021; 11(2-s):56-58

DOI: http://dx.doi.org/10.22270/jddt.v11i2-s.4646

*Address for Correspondence:

S. Shanmugam, Research Scholar, Post Graduate and Research Department of Botany, Thiagarajar College, 139-140, Kamarajar Road, Teppakulam, Madurai 625009, Tamil Nadu, India

\begin{abstract}
Preliminary phytochemical tests played a significant role in finding and locating chemica constituents which are source of pharmacologically active principles. By consider the medicinal importance of tuber of Acorus calamus, flower of Senna alata and fruit of Solanum torvum, the present study was designed to screen the phytochemical constituents present in such plant parts preliminarily. The phytochemical analyses were conducted by employing standard methods to detect the presence/absence of alkaloids, carbohydrates, flavonoids, glycosides, phenols, phytosterols, proteins, saponins and tannins. The results of present study revealed that alkaloids were found to be present in all the three plants analyzed and all the three solvents extracted, whereas, glycosides and phenols were absent. The acetone extract of Acorus calamus and Solanum torvum showed the presence more number of phytochemicals (4 each) and petroleum ether extract of Senna alata and Solanum torvum revealed the presence of only one compound. The potential active principles of the detected compounds should be quantified and pharmacologically evaluated.
\end{abstract}

Keywords: Preliminary phytochemical analyses, Acorus calamus tuber, Senna alata flower, Solanum torvum fruit.

\section{INTRODUCTION}

Nearly $80 \%$ of the world's population relies on traditional medicines for primary health care, mast of which involve the use of plant extracts ${ }^{1}$. The medicinal value of these plants lies in some chemical substances which are naturally occurring in various plant parts that produce a definite physiological action on the human body. The most important property of these bioactive constituents is that they are more effective with little or no side effects when compared to the commonly used synthetic chemotherapeutic agents. Qualitative phytochemical screening will help to understand a variety of chemical compounds produced by plants and also will help to extract, purify and identify the bioactive compounds for useful aspects to human beings ${ }^{2}$.

Acorus calamus L. belongs to the family Acoraceae and tuber of this species has been reported to use in the treatment of various ailments viz. its extract along with salt is given orally to cure stomach pain ${ }^{3}$; its extract is taken orally to treat dysentery 4 and its powder is applied to cure epilepsy 5 . Senna alata (L.) Roxb. belongs to the family Fabaceae and earlier report highlighted that paste made from the flowers of this species is applied to heal wound ${ }^{6}$. Solanum torvum Sw. belongs to the family Solanaceae and fruits of this species is cooked and eaten to control spleen enlargement ${ }^{7}$ and fruit juice is used to treat kidney stone ${ }^{8}$. Based on these ethnomedicinal importances of these plant parts in various regions of Tamil Nadu, such parts were selected to screen the phytochemical constituents preliminarily for present study.

\section{MATERIALS AND METHODS}

\subsection{Collection of plant materials}

The tubers of Acorus calamus L. (Acoraceae - Vasambu), flowers of Senna alata (L.) Roxb. (Fabaceae - Seemaiagathi) and fruits of Solanum torvum Sw. were collected from their natural habitats in Kathakinaru village (9.9865 $\mathrm{N}$ latitude and $78.1717^{\circ} \mathrm{E}$ longitude) of Madurai district in Tamil Nadu, India. The plant parts were washed separately with tap water and shade dried at room temperature to attain constant weight. The air dried samples were powdered in an electric blender and stored in plastic container for further analysis. The plants were botanically authenticated as per APG IV classification ${ }^{9}$.

\subsection{Preparation of plant extracts}

The powdered drugs of all the selected plant parts were extracted successively with acetone, ethanol and petroleum ether by hot extraction method separately. The extracted solvents were evaporated under reduced pressure using a rotary vacuum evaporator to get semisolid mass for further preliminary phytochemical analyses.

\subsection{Screening of phytochemicals}

All the plant extracts were screened for the presence of various phytoconstituents such as alkaloids, carbohydrates, flavonoids, glycosides, phenols, phytosterols, proteins, saponins and tannins according to the standard phytochemical methods ${ }^{10-13}$. 


\section{RESULTS AND DISCUSSION}

The findings of Acorus calamus tuber highlighted that acetone extract showed the presence of alkaloids, phytosterols, saponins and tannins, ethanol extract exposed the presence of alkaloids and saponins, and petroleum ether extract revealed the presence of alkaloids, saponins and tannins. Alkaloids were found in all the three solvent extracts screened and carbohydrates, flavonoids, glycosides, phenols and proteins were not found in the same. Most number of phytochemicals (4) was detected in acetone. The data regarding the presence and absence of various phytochemicals in tuber of Acorus calamus is pertained in Table 1.

In Senna alata flower extracted with acetone, alkaloids, flavonoids and saponins were found to be present. The ethanol extract of the same showed the presence of alkaloids, carbohydrates, flavonoids and saponins, and petroleum ether extract revealed the presence of alkaloids only. Alkaloids were found to be present in all the three solvents and glycosides, phenols, phytosterols, proteins and tannins were absent. Among the solvent extracts of Senna alata flower, ethanol extract exposed 4 compounds as maximum. All these results are featured in Table 2.

The results related to the preliminary phytochemical screening of Solanum torvum fruit are given in Table 3. According to that, acetone extract covered the presence of alkaloids, flavonoids, phytosterols and proteins, ethanol extract showed the presence of alkaloids, flavonoids and phytosterols, whereas the petroleum ether extract exposed the presence of alkaloids alone. In all the three extracts, alkaloids were present and carbohydrates, glycosides, phenols, saponins and tannins were found to be absent. Of the phytoconstituents analyzed, most of the compounds (4) were detected in ethanol extract than others (Table 3).

Table 1: Preliminary phytochemical screening of Acorus calamus tuber

\begin{tabular}{|l|c|c|c|}
\hline \multirow{2}{*}{ Phytochemical } & \multicolumn{3}{|c|}{ Solvent extract } \\
\cline { 2 - 4 } & Acetone & Ethanol & $\begin{array}{c}\text { Petroleum } \\
\text { ether }\end{array}$ \\
\hline Alkaloids & + & + & + \\
\hline Carbohydrates & - & - & - \\
\hline Flavonoids & - & - & - \\
\hline Glycosides & - & - & - \\
\hline Phenols & - & - & - \\
\hline Phytosterols & + & - & - \\
\hline Proteins & - & - & - \\
\hline Saponins & + & + & + \\
\hline Tannins & + & - & + \\
\hline
\end{tabular}

Table 2: Preliminary phytochemical screening of Senna alata flower

\begin{tabular}{|l|c|c|c|}
\hline \multirow{2}{*}{ Phytochemical } & \multicolumn{3}{|c|}{ Solvent extract } \\
\cline { 2 - 4 } & Acetone & Ethanol & $\begin{array}{c}\text { Petroleum } \\
\text { ether }\end{array}$ \\
\hline Alkaloids & + & + & + \\
\hline Carbohydrates & - & + & - \\
\hline Flavonoids & + & + & - \\
\hline Glycosides & - & - & - \\
\hline Phenols & - & - & - \\
\hline Phytosterols & - & - & - \\
\hline Proteins & - & - & - \\
\hline Saponins & + & + & - \\
\hline Tannins & - & - & - \\
\hline
\end{tabular}

Table 3: Preliminary phytochemical screening of Solanum torvum fruit

\begin{tabular}{|l|c|c|c|}
\hline \multirow{2}{*}{ Phytochemical } & \multicolumn{3}{|c|}{ Solvent extract } \\
\cline { 2 - 4 } & Acetone & Ethanol & $\begin{array}{c}\text { Petroleum } \\
\text { ether }\end{array}$ \\
\hline Alkaloids & + & + & + \\
\hline Carbohydrates & - & - & - \\
\hline Flavonoids & + & + & - \\
\hline Glycosides & - & - & - \\
\hline Phenols & - & - & - \\
\hline Phytosterols & + & + & - \\
\hline Proteins & + & - & - \\
\hline Saponins & - & - & - \\
\hline Tannins & - & - & - \\
\hline
\end{tabular}

On whole, the results of present study revealed that alkaloids were detected in all the three plants analyzed and all the three solvents extracted. This finding is corroborated with the outcome of earlier phytochemical analyses carried out on leaf extracts of these three plants ${ }^{14}$. Regarding the number of compounds detected, the acetone extract of Acorus calamus and Solanum torvum showed the presence more number of phytochemicals (4 each) as highest, and petroleum ether extract of Senna alata and Solanum torvum revealed the presence of only one compound each as least (Fig 1).

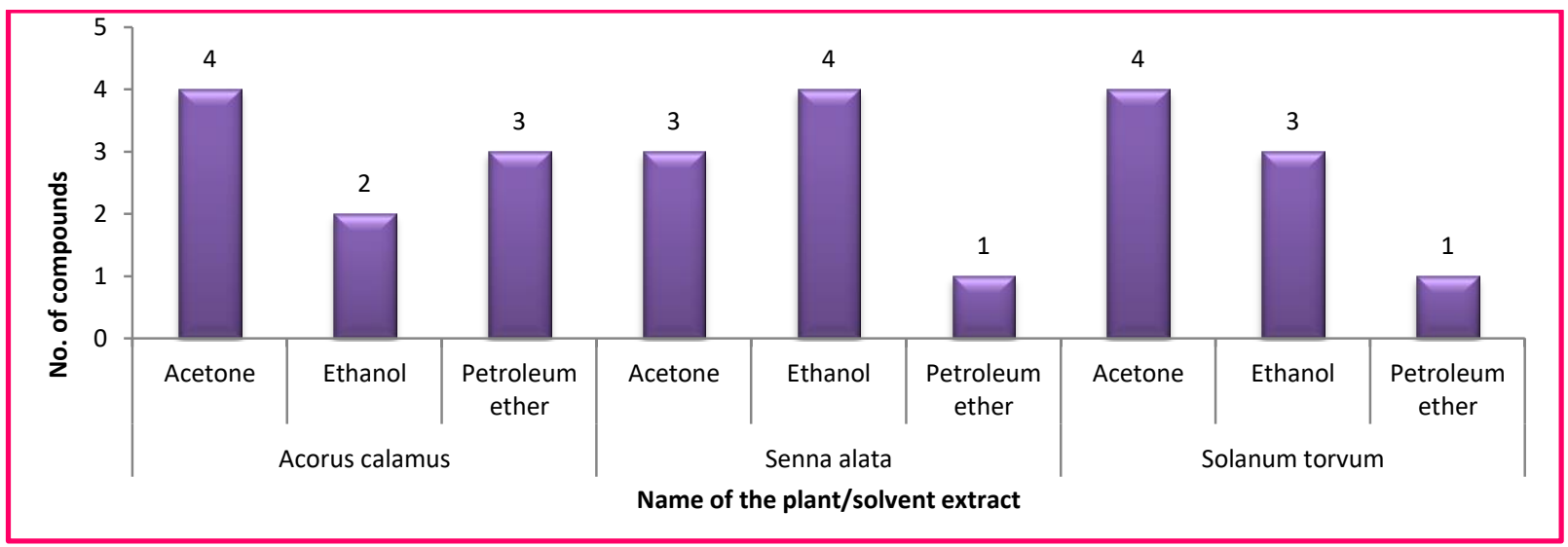

Figure 1: Number of compounds detected in respective plants and solvent extracts 
By the present study, it was also predicted that more number of phytochemicals were detected in acetone extract than that of ethanol and petroleum ether extracts. As per earlier reports, the recovery of phytochemical from plant sample could be influenced by dielectric constant, chemical structure of solvents used, and as well as chemical properties of phytochemicals 15 .

\section{CONCLUSION}

To isolate, identify and characterize the bioactive compounds present in tuber of Acorus calamus, flower of Senna alata and fruit of Solanum torvum further quantitative and chromatographic studies should be carried out, which ultimately ends in new drug invention. Pharmacological activities of these medicinally important parts should also be evaluated.

\section{CONFLICT OF INTEREST}

The authors have declared that there is no conflict of interest.

\section{REFERENCES}

1. Ahmed M, Rana AC \& Dixit VK. Calotropis species (Asclepiadaceae): A comprehensive review. Pharmacognosy Magazine, 2005; 2:48-52.

2. Mukherjee PK. Quality Control of Herbal Drugs. $2^{\text {nd }}$ Edition, Business Horizons; 2007; 2-14.

3. Jose FC \& Jayendran M. Toda ethnomedicine - A bioinformatic approach. Journal of Basic and Applied Biology, 2012; 6:25-28.

4. Shanmugam S, Balamurugan S, Pandiselvam P \& Rajendran K. Medicinal plants used by people of Thiruppuvanam and its surrounding areas of Sivagangai district in Tamil Nadu, Southern India. Journal of Basic and Applied Biology, 2012; 6:3945 .
5. Jeyanthi Y, Joselin J \& Suseela Bai C. Studies on phytotherapeutic plants of Agasteeswaram taluk, Kanyakumari district, Tamil Nadu, India. Journal of Basic and Applied Biology, 2012; 6:66-69.

6. Shanmugam S, Rajagopal V, Balamurugan S, Muthupandi CP, Eswaran VM, Raveendraretnam $\mathrm{K} \&$ Rajendran $\mathrm{K}$. Ethnobotanical indices on wound healing medicinal plants in the Arjuna river of Virudhunagar district in Tamil Nadu, Southern India. Asian Journal of Ethnobiology, 2021; 4(1):31-36.

7. Vijaya AMS. A survey of medicinally important plants in Thumpali hills - A Fragmented forest of Southern Western Ghats, Tamil Nadu, India. Journal of Basic and applied Biology, 2012; 6:9-14.

8. Vijaya AMS \& Jaisingh A. Traditional uses of dicotyledonous medicinal plants among the Kani tribes of Mothiramalai, Kanyakumari district (Western Ghats), India. Journal of Basic and Applied Biology, 2012; 6:15-20.

9. APG IV. An update of the Angiosperm Phylogeny Group classification for the orders and families of flowering plants. Botanical Journal of the Linnean Society, 2016; 181(1):1-20.

10. Trease \& Evans WC. Pharmacognosy. $14^{\text {th }}$ Edition, WB Saunders Ltd., London. 1966; 119-159.

11. Brain KR \& Turner TD. The Practical Evaluation of Phytopharmaceuticals. $1^{\text {st }}$ Edition, Wright Science Technical, Bristol Britain. 1975.

12. Harborne JB. Phytochemical methods: A Guide to Modern Technique of Plant Analysis. Champman and Hall Publishers. London. 1998.

13. Mukherjee PK. Quality Control of Herbal Drugs. Business Horizons Pharmaceutical Publishers, New Delhi. 2010.

14. Mohan E, Suriya S, Shanmugam S, Rajendran K. Qualitative phytochemical screening of selected medicinal plants. Journal of Drug Delivery and Therapeutics, 2021; 11(2):141-144.

15. Felhi S, Daoud A, Hajlaoui H, Mnafgui K, Gharsallah N \& Kadri A. Solvent extraction effects on phytochemical constituents profiles, antioxidant and antimicrobial activities and functional group analysis of Ecballium elaterium seeds and peels fruits. Food Science and Technology (Campinas), 2017; 37(3):483-492. 